Western University

Scholarship@Western

Surgery Publications

Surgery Department

$9-2005$

\title{
Clinical Kidney Transplantation: A 50th Anniversary Review of the First Reported Series
}

Vivian Charles McAlister

The University of Western Ontario

Follow this and additional works at: https://ir.lib.uwo.ca/surgerypub

Part of the History of Science, Technology, and Medicine Commons, and the Surgery Commons

Citation of this paper:

McAlister VC. Clinical kidney transplantation: a 50th anniversary review of the first reported series. Am J Surg 2005

Sep; 190(3):485-8. 


\title{
Clinical kidney transplantation: a 50th anniversary review of the first reported series
}

\author{
Vivian Charles McAlister, M.B., F.R.C.S.C.* \\ Department of Surgery, University of Western Ontario, London, Ontario, Canada N6A 5A5
}

Manuscript received August 4, 2004; revised manuscript April 4, 2005

\begin{abstract}
Background: Histories of kidney transplantation rarely mention a series reported by Gordon Murray of Toronto and published by the American Journal of Surgery 50 years ago.

Methods: The papers and biographies of Gordon Murray were reviewed in the context of knowledge at that time about renal failure management to determine their contribution to transplantation research and to current practice.

Results: Murray proceeded from a unique leadership position in vascular surgery, anticoagulation therapy, and dialysis to undertake a rational series of animal experiments and human trials of kidney transplantation that led him to the practices of graft irrigation, cold storage, pelvic graft placement, renal-to-iliac vascular anastomoses, and ureterovesical anastomosis that continue to be used today. His animal studies included the first attempts to use immunosuppression and total body irradiation to prevent rejection. His observation that rejection may result in graft thrombosis and his attempts to prevent it with heparin anticipated current efforts to use newer agents for the same purpose in sensitized allotransplantation and xenotransplantation.
\end{abstract}

Conclusions: Modern renal transplantation is founded on many of the principles expounded by Gordon Murray 50 years ago. ㄷ 2005 Excerpta Medica Inc. All rights reserved.

Keywords: Kidney transplantation; Gordon Murray; History of medicine

In May 1954, the American Journal of Surgery published the first series of clinical kidney transplantation [1]. Although provenance is as important in transplantation as in any other area of surgery, this article is rarely cited and its primary author, Gordon Murray, is not considered to be a pioneer of kidney transplantation [2]. It is believed that he was a technically gifted operator who turned his hand to many diverse areas of surgery but that he had insufficient knowledge of transplantation immunology to be so considered [3]. In December 1954, the Toronto report was overshadowed by news from Boston of successful kidney transplantation between identical twins [4]. Even though this operation sidestepped the immunologic issues of transplantation, it is now considered the beginning of modern kidney transplantation on the basis of progressive extension of the technique to more disparate pairs [5]. Gordon Murray, probably in an effort to subsidize his privately funded research

\footnotetext{
3858 .

* Corresponding author. Tel.: +1-519-663-2920; fax: +1-519- 663-

E-mail address: vmcalist@uwo.ca
}

facility, moved to cancer research [6] and, ultimately, to experiments in spinal cord regeneration [7]. His eclipse was completed by accusations of fraudulent surgery arising out of premature claims of successful spinal cord repair, which resulted in his retirement at the age of 75 [3].

\section{Early Years}

Gordon Murray grew up on a farm in western Ontario, where improvisation and "making do" were a way of life. After graduation from the University of Toronto in 1921, he apprenticed with a country surgeon, Dr Lorne Robertson, in the small Ontario town of Stratford. Again improvisation was frequently required [8]. This was the time of the frenzy in Toronto regarding the discovery of insulin. The atmosphere of innovation and success imbued Murray with a pioneering surgical spirit. After 18 months of country practice, he sought out formal surgical training in London, New York, and Toronto. In 1927, he was appointed to staff in Toronto where one of his duties was to lecture the students on a very broad range of basic medical topics [3]. Almost 
immediately he began to develop new surgical treatments, which included internal stenting of the malignant esophagus (1931) and bone autotransplantation for scaphoid non-union (1934) [3].

Charles Best, who had worked with Banting on the discovery of insulin, sought him out to help with the development of heparin. A successful series of animal experiments and clinical trials established Murray as a leading academic cardiovascular surgeon. He pioneered the treatment of deep vein thrombosis and pulmonary embolism, arterial embolectomy, cardiac valve surgery, and interventicular septal defect repair. He was particularly adept at the Blalock-Taussig repair and his practice established Toronto as a center for surgical treatment of congenital heart disease.

\section{Invention of a Dialysis Machine}

Murray duplicated Alexis Carrel's models to test heparin in animals. In the 1930s he autotransplanted kidneys into the neck of dogs [9]. At the time, he did not consider kidney transplantation as a therapy but as a model of thrombosis. Another model that he tested was the passage of blood through tubes. Once he observed that heparin prevented clotting, he realized an indefinite extracorporeal circulation was possible. Casting around for "tissues, membranes or substances [that] could be placed in circuit to remove poisonous substances" from the blood, he realized he might be able to imitate the "action of a normal kidney" [10].

With a visiting trainee, Edmund Delorme of Edinburgh, and a student chemist, Newell Thomas, Murray started construction of "an artificial kidney" in 1945. The team tested many natural and synthetic sheets before settling on sausage casing made of cellulose as a membrane. They quickly switched from tap water to Ringer's solution for dialysate and finally they devised an external pump to run a veno-venous circuit because use of an arterial inflow was found to be inefficient. In 1946, the first patient was dialyzed. The machine maintained a young woman who was dying of acute renal failure as a consequence of a back street abortion, until her own kidneys recovered. Murray presented the results of a series of patients to the Central Surgical Association in Chicago in 1947 and papers were published in various American and British journals over the next few years [11].

Murray was unaware of the work of Willem Kolff, who had designed a dialysis machine in 1943 in occupied Holland. Both machines used a cellulose membrane, but Kolff wound his tube around a cumbersome rotating drum and employed the pressure of a femoral artery inflow to power the circuit. It is interesting to note, in the light of Murray's transplantation legacy, that Kolff is today considered the inventor of dialysis even though it is Murray's designs that are currently used. In 1947, Kolff was invited to the Brigham Hospital in Boston by George Thorn to present Grand Rounds on his pioneering work in dialysis. Thorn, who was chief of medicine, arranged for John Merrill and Carl Walter to collaborate with Kolff in refining the machine, which became known as the Kolff-Brigham artificial kidney [12].

\section{Preclinical Transplant Research}

Murray did not think it would ever be feasible to treat chronic renal failure by dialysis. This was at a time when chronic venous access was not available. He was, however, uniquely placed to consider kidney transplantation, which he felt offered to only hope of long-term survival without native kidney function. Since the end of the Second World War, Murray had become increasingly frustrated with the failure of the Toronto General Hospital and the University of Toronto to capitalize on his pioneering efforts in the way American centers had supported their research successes. He was concerned about younger rivals such a William Bigelow and William Mustard who had returned from the war as experienced surgeons. With the retirement of his protector Dr William Gallie from the chair of surgery, Murray felt threatened and he set up an independently funded research institute outside of the university. The initial goal of the unit was to overcome the barriers to kidney transplantation [3].

In 1946, Charles Hufnagel and David Hume at the Brigham Hospital, at the suggestion of George Thorn, attached a kidney to the antecubital vessels of a woman dying in circumstances identical to Murray's first dialysis patient [12]. The patient was revived with the temporary transplant, which survived until spontaneous recovery of the native kidneys occurred. Murray tried the same technique but was dissatisfied with the renal function, which he put down to insufficient blood flow from the arm [1]. He began a series of animal experiments to isolate and overcome each problem.

Murray started with autotransplantation in dogs to determine the best technique for donor nephrectomy, optimum storage conditions, and maximum storage time in order to facilitate graft retrieval from a deceased donor. He determined that it was important to clamp the renal artery before the vein in the donor to avoid parenchymal barotrauma. He irrigated the kidneys with Ringer's solution and he covered them with a saline-soaked gauze. He was aware of Bigelow's experiments with hypothermia in cardiac surgery and he discovered that cooling the kidneys down to between 10 and $4^{\circ} \mathrm{C}$, using cooled perfusate and a bed of ice cubes, increased the cold storage viability time from 2.5 hours at room temperature to 5 hours. To determine long-term function he transplanted stored kidneys into nephrectomized dogs using renal to iliac vessel anastomoses [1]. He was able to achieve consistent long-term survival of stored kidneys autotransplanted in dogs and he performed a longitudinal study of the renal transplant pathology.

When he moved into a canine model of allotransplantation, Murray encountered difficulties most of which he 
attributed to vascular thrombosis. He added heparin to the perfuasate without effect. He tried heparinization of the animals. Many of the animals died of hemorrhage, but a few survived up to 11 days. Murray decided the difference in results between autotransplantation and allotransplantation was an "immune reaction," which he unsuccessfully tried to counter first with pyribenzamine and then with total body irradiation. Finally he tried desensitization by injecting increasing aliquots of mashed tissue from the opposite donor kidney, a maneuver that not only failed to prevent but appeared to accelerate thrombosis of the graft [1].

\section{The First Modern Kidney Transplantation Series}

In 1950, Richard Lawler of Chicago orthotopically transplanted a left kidney without immunosuppression into a patient with renal insufficiency due to polycystic disease. Excretion of dye from the left ureter was demonstrated at 52 days but all function was lost by 9 months [13]. This report, described by those working in the field as a "bombshell" [14], stimulated simultaneous but independent attempts at clinical transplantation in Boston, Toronto, and Paris. David Hume in Boston first tried to repeat the Lawler procedure but abandoned it in favor of graft placement in the thigh with a uretero-cutaneous fistula at the knee [12]. In Paris, 3 separate teams worked on kidney transplantation. Rene Kuss placed the graft in the pelvic position. He anastomosed the donor renal artery end-to-end to the hypogastric (internal iliac) artery but, like Hume, he used a cutaneous ureterostomy [14]. Murray had decided on the basis of his neck autotransplantation experience of the 1930s to avoid external drainage of the ureter because of infection. He perfected uretero-cycstostomy of a pelvic kidney transplant in the dog and determined to use it in humans [1].

Starting in 1951, Murray performed a series of 4 deceased donor kidney transplants using his heterotopic technique [3]. The team included nurse Rita Smith, anesthetist Stephen Evelyn, and resident William Lougheed. Both the deceased donor and the prospective recipient were operated on in the same room, Operating Room "C" at the Toronto General Hospital, separated by a screen. Lougheed quickly retrieved and cooled the graft with heparin and $8 \mathrm{~L}$ of Ringer's solution while Murray prepared a retroperitoneal space in the recipient's iliac fossa $[1,10]$. The graft was brought to the recipient and the best location for transplantation determined. End-to-side anastomoses between the donor renal vessels and the recipient iliac vessels were made with 5.0 arterial silk suture applied in an interrupted everting fashion first to the veins and then the arteries. The recipient was given heparin intravenously before removal of the venous clamps, which was followed by removal of the arterial clamps. The kidney was seen to make urine during dissection of the bladder and creation of the uretero-cystostomy [10].

All of the candidates were considered to be in the final stages of chronic renal failure. Of the first 3 recipients, the longest survivor lived 12 days, even though urine excretion and serum biochemical improvement were observed. On May 2, 1952, Murray's fourth patient was a 26-year-old woman who had been diagnosed with Bright's disease, 18 months previously. She had severe hypertension, 50 pounds of edema, azotemia, and a urine-specific gravity of 1,005 [1]. Murray and Lougheed successfully performed the transplant in front of a large number of onlookers from the hospital [10]. The patient made a spectacular recovery with loss of all the edema and concentration of the urine to a specific gravity of 1,020 . Murray attempted to demonstrate kidney function with an intravenous pyelogram. No function was seen in the native kidneys. Dye was seen in the bladder, but the graft could not be seen against the wing of the ilium [1]. The patient remained well for at least the next 21 years and the kidney was never removed [3]. In his report to this journal, Murray admitted that while "this patient might have returned to this sort of good health independently," he remained convinced of the importance of the transplant in achieving that state [1].

\section{Conclusions}

The Toronto kidney transplant series of 1951-52 was a logically planned clinical research program that fit into the continuum of not only its principal's research and clinical experience but also of transplantation research elsewhere in the world at that time. Murray presented his findings to several North American and International meetings. His report was published months before the identical twin transplantation, in which the Boston team switched from the Hume thigh technique to one similar to Murray's. The report of the Toronto series to this journal documented for the first time many practices in kidney transplantation that remain current today. These practices are not only clearly outlined, but their origin in thought and experiment is also documented. The experimental program may have been the first to examine immunosuppression by chemotherapy or irradiation even if the authors too readily gave up with negative results.

Gordon Murray's oft dismissal as a surgeon without knowledge of immunobiology is not valid. His description of thrombosis and necrosis with accelerated rejection is accurate as are his histologic descriptions of less severe rejection. Examining the long-term autotransplants that failed, Murray noted "fibroplasia ... . about the adventitia of blood vessels," which resulted in "the organ [being] replaced practically completely by adult fibrous tissue with full-sized degenerated parenchymal cells surrounded by [a] lymphocytic infiltrate [that] was relatively slight" [1]. This might be taken as the first description of what today is termed chronic "transplant nephropathy." In dealing with allotransplantation, Murray discussed 3 forms of immune reaction: "(1) a hypothetical cyctotoxic antibody; (2) a lympho[cy]tic infiltration; or (3) a replacement by fibrosis." 
Finally, he discovered that prior immunization resulted in an immune reaction that was more "rapid and extensive" than that seen without immunization, which might be considered the first description of hyperacute rejection. One could claim that Murray did not understand what he was writing, but he did manage to describe the different forms of rejection with uncanny accuracy before these forms were known or named. The fact that he chose to intervene most vigorously in the prevention of thrombosis is a reflection of his own research success and not a dismissal by him of other aspects of immunity. There are those today trying to overcome the barriers to sensitized allotransplantation or xenotransplantation who would find some appeal in Murray's belief that a vascularized organ transplant differed from skin transplantation in that the encounter between recipient blood and donor endothelium was the key to successful transplantation.

Murray's resident, Bill Lougheed, went to Boston in late 1954 to complete laboratory training. On his return to Toronto he became a neurosurgeon and he applied his experience to pioneer hypothermia and temporary circulatory arrest in aneurysm surgery. So why is Murray forgotten? The spectacular success of the Boston program not only overshadowed his work, but its team approach contrasted sharply with Murray's individualistic method. At the time of his report to the American Journal of Surgery, Murray had become alienated from his hospital and university authorities. He probably believed that support of his corporate benefactors depended on newsworthy as opposed to academic success. Ironically, in his switch to cancer research, he attempted to raise anticancer antibodies in horses using methods that would have given him antilymphocyte serum had he chosen to do so. Murray's transplantation flaw was his prospect of success in other areas. His papers are written in an imprecise pre-war narrative style. The media's insatiable appetite for instant success, coupled with Murray's increasing imprecision, resulted in his downfall at a time when he should have retired from a glorious career. His last contribution to transplantation was to prove experimentally that cardiac valves are not rejected in the same way as organs and to perform, in 1955, the first heart valve transplantation in a human [3].

\section{References}

[1] Murray G, Holden R. Transplantation of kidneys, experimentally and in human cases. Am J Surg 1954;87:508-15.

[2] Terasaki PI, History of Transplantation: Thirty Five Recollections. Los Angeles, CA: UCLA Tissue Typing Laboratory; 1991.

[3] McKellar S. Surgical Limits. The Life of Gordon Murray. Toronto, Canada: University of Toronto Press; 2003.

[4] Merrill JP, Murray JE, Harrison JH, et al. Successful homotransplantation of the human kidney between identical twins. JAMA 1956; 160:277-82.

[5] Moore FD. A Nobel Award to Joseph E. Murray, MD: some historical perspectives. Arch Surg 1992;127:627-32.

[6] Murray G. Experiments in host resistance to cancer. Am J Surg 1965;109:763-4.

[7] Murray G. Regeneration in injured spinal cord. Am J Surg 1965;109: 406-9.

[8] Murray G. Medicine in the Making. Toronto, Canada: Ryerson Press; 1960.

[9] Murray G. Heparin in thrombosis and embolism. Br J Surg 1940;27: 567-98.

[10] Murray G. Quest in Medicine. Toronto, Canada: Ryerson Press; 1963.

[11] Murray G, Delorme E, Thomas N. Development of an artificial kidney. Arch Surg 1947;55:516-22.

[12] Moore F. A Miracle and a Privilege. Boston, MA: Joseph Henry Press, 2001:157-210.

[13] Lawler RH, West JW, McNulty PH, et al. Homotransplantation of the kidney in the human; supplemental report of a case. JAMA 1951; 147:45-6.

[14] Kuss R. Human renal transplantation memories, 1951 to 1981. In: Terasaki PI, editor: History of Transplantation: Thirty Five Recollections. Los Angeles, CA: UCLA Tissue Typing Laboratory; 1991:3957. 